\title{
Implementation and Results of a New Problem Solving Approach in Physics Teaching
}

\author{
Elif Ince \\ Department of Science Education, Hasan Ali Yucel Education Faculty, Istanbul University-Cerrahpasa. \\ 34452, Istanbul-Turkey \\ elifince@istanbul.edu.tr
}

\begin{abstract}
Teaching problem solving is one of the most important topics of physics education while students have big troubles with physics problem-solving. The aim of this research is to investigate the impact of extended problem-solving strategy instruction on the development of pre-service science teacher's problem-solving, critical thinking, metacognitive awareness, and logical reasoning skills. Extended Problem-Solving Strategy has been developed for university physics courses by the researcher. This strategy has importance in terms of covering many previous strategies in physics education literature and including many new steps. The model of the research consisted of an experimental design with pre-test and post-test control groups. Preservices randomly assigned to the experimental $(\mathrm{N}=30)$ and control groups $(\mathrm{N}=30)$. The results of the research indicate that the post scores of the experimental group students significantly higher than control group students after the implementations in terms of metacognitive awareness, critical thinking, problem solving and logical thinking skills. This research revealed the positive effects of the "Extended Problem-Solving Strategy" implementation in the physics course at the university level on the skills which are listed among the 21st Century skills and each of these skills affects the other skills positively.
\end{abstract}

Keywords: Problem-solving strategy; physics education; metacognitive awareness skills; critical thinking skills; problem solving skills; logical thinking skills

\section{Introduction}

\subsection{State of the Problem Solving in Physics}

Teaching problem solving is one of the most important topics in physics education. While students are trying to solve physics problems, students often express that they understand the questions, they know the laws of physics on which the problem is based they have solved many similar problems, but the new problem is different from the previous problems, therefore, they cannot solve the problem. When existing studies in the literature are examined it has seen that various problem-solving strategy implementations improve students' problem-solving skills, performances, and achievements for many years. Dufrense, Gerace, and Leonard (1997) was applied an alternative method to students in the use of problem-solving strategies and the result revealed that two-thirds of the students in the experiment group had the ability to write adequate strategies for the solution and they performed more successfully than the control group students in terms of which concepts and principles were required for the problems (Dufrense, Gerace, \& Leonard, 1997). Çalışkan (2007) examined the effects of teaching problem-solving strategies on the achievement, attitudes, self-efficacy, problem-solving strategy usage skills, and problem-solving performances of first-year university students in the physics course. The research indicated that problemsolving strategies teaching had positive effects on physics achievement, attitude toward physics, physics self-efficiency and physics problems-solving (Çalışkan, 2007). Selçuk, Çalışkan, and Erol (2008) investigated

How to Cite:

Ince, E. (2019). Implementation and Results of a New Problem Solving Approach in Physics Teaching. Momentum: Physics Education Journal, 3(2), 58-68. https://doi.org/10.21067/mpej.v3i2.3396 
the effects of problem-solving strategy used in university physics courses on students' physics success, problem-solving performances and problem-solving strategy skills. Physics achievements, problem-solving performances and using problem-solving strategies skills of the students were found to be high at significant levels in this study (Selçuk, Çalışkan, \& Erol, 2008). Marlina, Nor Hasniza, Abdul Halim, Johari, and Nurshamela (2014) investigated how it could be determined of students' achievement in physics problem-solving.

According to the results of this study, students who can use the metacognitive problem-solving strategy are successful and at the same time expert problem-solvers (Marlina, Nor Hasniza, Abdul Halim, Johari, \& Nurshamela, 2014). Gök (2014) explored the effects of using phased problem-solving strategies on students' achievement, problem-solving skills, and self-confidence in problem-solving. The study revealed that the use of phased problem-solving strategies increases students' physics achievement, problemsolving skills in physics, and problem-solving self-confidence in physics (Gök, 2014). In another study, Gök (2015) showed the effects of the problem-solving strategy realized through peer tutoring in the university physics courses on the students' physics achievement and problem-solving skills. The results of the study showed that the experiment group students' homework performance, achievement scores in physics and visualization, problem-solving and solution control skills improved highly while there was no differentiation in the control group students' homework performance, achievement scores in physics and ability to apply problem-solving strategies (Gök, 2015). Docktor, Strand, Mestre, and Ross (2015) presented how physics teachers apply the conceptual physics problem-solving method and their results in high school physics classes. According to the results of the study, the teachers stated that this practice would be easily adaptable to the curriculum and that the students had higher problem-solving skills and achievement grades (Docktor, Strand, Mestre, \& Ross, 2015). Halim, Yusrizal, Susanna, and Tarmizi (2016) investigated the ability of students' problem-solving strategies in physics. According to the results of the study, it was determined that the students had difficulty in identifying the problem (Halim, Yusrizal, Susanna, \& Tarmizi, 2016).

\subsection{Gap Analysis}

Some of the $21^{\text {st }}$ century skills are categorized as critical thinking, creative thinking, logical reasoning, metacognitive awareness and problem-solving (Häkkinen, Järvelä, Mäkitalo-Siegl, Ahonen, Näykki, \& Valtonen, 2017). Critical thinking signifies an active and organized mental process as well as an impulse, aiming to understand the events, situations, and thoughts. The ability to enable a person to think critically is based on the person's tendency to seek and search clarity, take an intellectual risk, and thus, think critically. Hence, the tendencies in the literature as classified as open-mindedness, curiosity, searching for truth, being analytical, systematicity, self-confidence on critical thinking (Bissell \& Lemons, 2006). Logical Reasoning involves forming a result at the end of a logical decision-making process. It is necessary to teach the prominence of using problem solving skills to gain logical thinking capabilities. Logical reasoning and critical thinking skills are among the metacognitive skills and take place in the upper level of the Bloom's taxonomy (Bissell \& Lemons, 2006). Logical Reasoning requires an effective knowledge and comprehension step in the level of cognitive knowledge (Tobin \& Capie, 1982). Logical reasoning processes are controlling variables, proportional thinking, probabilistic thinking, and relational thinking. Logical reasoning strategies also facilitate day-to-day problems as well as improving problem solving and enhancing achievements (Lawson, 1982). Metacognitive awareness is a skill enable a person to determine the roadmap for the purpose and to process the individual by himself / herself by taking into account the needs of the individual and to evaluate of learning process (Ertmer \& Newby, 1996).

The studies emphasized that there is an interaction between logical reasoning, critical thinking, metacognitive awareness and problem-solving skills and any change in one skill affects the others (Häkkinen, Järvelä, Mäkitalo-Siegl, Ahonen, Näykki, \& Valtonen, 2017). In addition, when the existing 
literature is examined in physics education, it has seen that problem solving process is an activity that requires field knowledge and appropriate cognitive strategies that were expected from students and a necessity arise new strategies on problem solving strategies.

In fact, these skills are related to each other and take place in the upper level of the Bloom's taxonomy (Bissell \& Lemons, 2006; Tezbaşaran, 2011). The problem-solving work done to date, at least three levels of Bloom's taxonomy were reached. Extended Problem-Solving Strategy has an importance terms of covering many previous strategies in physics education literature and including many new steps. It is believed to reach level of metacognition by using Extended Problem-Solving Strategy teaching. are associated with high-level learning skills such as creative thinking, critical thinking, and logical reasoning, as mentioned above. It is considered that the development of each skill also creates a developing effect to each other.

\subsection{Novelty of the Research}

Extended Problem-Solving Strategy has been developed for university physics courses by the researcher (Ince, 2017). It has importance in terms of covering many previous strategies in physics education literature and including many new steps. The main steps of the Extended Problem-Solving Strategy, as well as sub-steps, are below.

1-Understanding of the Problem

- Identifying of given variables and writing with units

- Determining of desired variables and writing with units

- Identification based on the concept of the problem

- Rewriting of the problem with their sentences

- Visualizing of the problem (picture, diagram, graphic, etc.)

- Making plans for the solution/s (flow diagram, statements, pictures, etc. can be used)

- Giving daily life examples which are based on these concepts involved in the problem

2-Solving of the Problem

-Writing of formulas and equations that can be used for the solution

- Establishing, writing and sorting of equations which will lead to solving by using formulas and equations

- Implementing the solution

- Expressing of other possible solutions if any

3- Checking of the Problem Solving

- Checking mathematical results using calculator

- Crosschecking of the desired and given variables

- Crosschecking of the problem result and reasonable explaining of units

- Implementing of the other possible solutions and crosschecking of the results, if any

- Explaining the relationship between variables (increase, decrease, no change, etc.)

4-Penetrating of the Problem

- Writing of the problems again by changing the locations of the desired and given variables taking into consideration all possibilities

- Specifying what variables or results can be reached by using equations other than the desired variables

- Writing and solving a new problem by using the concepts and principals involved in the solved problem

5- Transferring of the Problem

- Explaining what type of problem will be solved in everyday life related to solved problem's concepts and principles 
- Drawing of an image of the suggested product that can be created for stated problem and explaining of each part

- Making of a plan for the establishment of this product

- Stating additional or missing concepts and information if necessary for the stated problem-solving.

Understanding of the Problem is the first step of the Extended Problem-Solving Strategy. In this step students are expected to do as follows; identifying of given variables and writing with units so that they realize what are they trying to solve; listing the concepts on which the problem is based and explaining the concepts so that they understand whether they have or not the requested information; expressing the problem with their own sentences so that they completely understand the question in the problem; visualizing the problem so that they conceptualize the problem together with its details and variables; making plan for the solution so that they define the strategy; giving examples from daily life so that they realize if they understand the problem correctly or wrongly. Solving the Problem is the second step of the Extended Problem-Solving Strategy. In this step, students are expected to do as follows; writing in detail the formulas and equations they are will be using when solving the problem so that they understand whether they have or not the knowledge needed to solve the problem; equating by using formulas and equations so that they implement the strategy they define themselves; implementing the solution so that the strategy they designed is useful or not. Checking of the Problem Solving is the third step of the Extended ProblemSolving Strategy. In this step, the students are expected to; checking mathematical results using a calculator, crosschecking of the desired and given variables, implementing other possible solutions and crosschecking of the results so that they ensure that their strategy is correct; explaining scientifically the result in terms of unit and explaining of relationship between variables so that recognize the correctness of the result. The first three steps of the Extended Problem-Solving Strategy develop particularly critical thinking as well as metacognitive skills. Penetrating the Problem is the fourth step of the Extended Problem-Solving Strategy. In this step, students are expected to do as follows; editing the statement of each problem by changing the location of required and given variables for all possibilities, specifying what variables or results can be reached by using equations other than the desired variables so that the students realize all possibilities including all problems; writing and solving of a new problem by using the concepts and principals involved in the solved problem so that they realize how well they understand and use the concerned concepts. This step of the Extended Problem-Solving Strategy develops the whole of creative thinking, critical thinking, and metacognitive skills. Especially, it is possible to state that when the student has developed creative thinking skills, the number of possibilities that the students will be able to specify when $s /$ he is demanded to specify the desired variables increases. Hence, $s /$ he will be more successful to identify other variables or results that are possible to reach and to reach the desired variables by changing the locations of all possibilities. Transferring of the Problem is the fifth step of the Extended ProblemSolving Strategy. In this step, students are expected to do as follows; explaining of what type of problem will be solved in everyday life related with solved problem's concepts and principles so that they can use in practice the problem; drawing of an image of the suggested product that can be created for stated problem and explaining of each part; for establishing of this product so that they can organize their knowledge and apply this knowledge to a new situation; stating additional or missing concept and information if necessary for the stated problem solving so that they realize what is missing in their plans to ensure a solution. This step of the Extended Problem-Solving Strategy develops the whole of creative thinking, critical thinking, and metacognitive skills. Especially, by organizing the knowledge that the students possess, they create a solution to a daily problem, visualize the solution with a model and strive to explain all possible parts and to define alternatives. Hence, they develop their creative thinking skills. It is possible to state that the more unique the product the students imagine, the more creative they can be. The order of the specified substeps can be altered considering the skills or needs of the students. 


\section{Method}

\subsection{Purpose of the Research}

The problem statement of the research is defined as "What are the effects of the extended problemsolving strategies, which was implemented during the physics course on the pre-service science teacher's problem-solving, critical thinking, metacognitive awareness, and logical reasoning skills, in comparison with traditional physics instruction?". Sub-problems addressed in this context are stated below;

- What is the effect of the extended problem-solving strategy implementation in the physics course on the problem-solving, critical thinking, metacognitive awareness, logical reasoning skills of the pre-service science teachers compared to the traditional physics instruction?

- Do the experimental group's post-test scores of problem-solving skills, critical thinking skills, metacognitive awareness skills, and logical reasoning skills have a meaningful correlation with each other?

- Are the problem-solving skills of the experimental group significantly improved?

\subsection{Model of the Research}

The model of the research consists of an experimental design with pre-test and post-test control groups. While the experimental group studied Physics I course based on Extended Problem Solving Strategy implementation which is developed by the researcher; the control group studied physics in the traditional approach. The Physics I course consists of six lesson hours (45 minutes) of lecture per week. Within the scope of Physics I in Science Education Program of Faculty of Education in Turkey, following subjects are studied; SI units, One Dimensional Motion, Vectors, Two Dimensional Motion, Kinematics, Dynamics, Energy, Work, Power, Mechanical Energy, Impulse-Momentum, Rotational Motion, Mechanical Properties of Matter, Harmonic Motion.

\subsection{Sample of the Research}

This research was conducted at pre-service science teachers studying Physics I course at the Department of Science Education in Turkey during the fall semester of the 2017-2018 academic year. The participants of the research were 60 pre-service science teachers ( 41 females and 19 males) ranging in age from 19 to 21 years old and come economically from the middle-class family. High School Graduation Grade of the pre-service science teacher's 80 and above out of 100 grades. Experimental and control groups of the research were selected randomly and consisted of 30 individuals. When selecting the samples, there is a requirement to strictly adhere the rule of neutrality to prevent the influence of subjective factors such as the researcher's partiality, volunteers or selecting the easiest sample to find (Moser \& Kalton, 1971). To determine homogeneous layer in the universe according to one or more variables considered effective on the problem of the research, using a random sampling technique and taking into consideration the data obtained from pre-tests, sex, and age variables formed groups.

\subsection{Instrument and Procedures}

Problem-Solving Inventory, Metacognitive Awareness Inventory, Logical Reasoning Test Inventory, and Critical Thinking Inventory were used as quantitative data collection measurement tools to investigate the effect of problem-solving strategy instruction. Within the scope of the research, the Problem-Solving Inventory (PSI), which is developed by Heppner and Peterson (1982) used in the Turkish version by Şahin, Şahin, and Heppner (1993). PSI is a 35-item and 6 sub-factors. The Cronbach's alpha coefficient of reliability of the scale was .90 (Heppner \& Peterson, 1982; Şahin, Şahin, \& Heppner, 1993). Critical Thinking Test was developed by Facione, Facione, and Giancarlo (1992) was used to determine the students' tendencies of critical thinking in the research. Kökdemir (2003) adapted this test into Turkish (Facione, Facione, \& Giancarlo, 1992; Kökdemir, 2003). The Turkish version of the scale consists of 51 items and 6 sub-scale. 
Cronbach's alpha coefficient of reliability of the scale was .88. Schraw and Dennison (1994) investigated the fundamental structures of metacognition and developed the Metacognitive Awareness Inventory (MAI) to evaluate the awareness of metacognition in adolescents and adults. Akın, Abacı, and Çetin (2007) adapted the inventory into Turkish. Turkish version of the scale consists of 52 items and 8 sub-scale. The Cronbach's alpha coefficient of reliability of the scale was .95 (Schraw \& Dennison, 1994; Akın, Abacı, \& Çetin, 2007). Tobin and Capie (1981) developed an authentic and reliable measurement tool that facilitates the implementation and ensures the objective scoring to measure Logical Reasoning. The test consists of two questions for each of the five reasoning models for 10 items. Reliability for the Logical Reasoning test was reported as.81 (Tobin \& Capie, 1981). This test was translated and adapted into Turkish by Geban, Aşkar, and Özkan (1992). The Cronbach Alpha reliability of the test was found as .77 (Tobin \& Capie,1981; Geban, Aşkar, \& Özkan,1992).

\subsection{Implementation}

In the experimental group; before the application, pre-service science teachers were explained about the Extended Problem-Solving Strategy together with the details and 3 examples so that the students perceive the whole process with its details. Then problem-solving strategy implementation was performed weekly. For a total period that took 12 weeks for the following subjects; SU units, one-dimensional motion, vectors, two-dimensional motion, kinematics, dynamics, energy, work, power, mechanical energy, impulsemomentum, rotational motion, mechanical properties of matter, harmonic motion. At the end of each week, students were given a problem together with homework to present the details of the corresponding week for the usage of the Extended Problem-Solving Strategy by themselves. The instructor did not assist in this process. The implementation lasted in 12 weeks. Before and after the application, quantitative data collection tools were applied as the pre-test, post-test. Also, experimental group students participated to the "Patenting Turkey Competition" which took place for undergraduate students in Turkey (Patenting Turkey, 2018) with their developed products at the last step of Extended Problem-Solving Strategies which is transferring section.

In the control group, the traditional approach was applied. In traditional approach, students were trained with the same problems about SU units, one dimensional motion, vectors, two dimensional motion, kinematics, dynamics, energy, work, power, mechanical energy, impulse-momentum, rotational motion, mechanical properties of matter, harmonic motion subjects without any strategy implementation by the same instructor weekly. At the end of each week, students were given a problem as homework from Physics for Scientists and Engineers book (Serway \& Beichner, 2007). The implementation lasted in 12 weeks. The instructor did not assist in this process. Before and after the application, quantitative data collection tools were applied as the pre-test, post-test. Control group students were also encouraged to participate in the "Patenting Turkey Competition" which took place for undergraduate students in Turkey (Patenting Turkey, 2018) but students did not want to participate in the competition.

\subsection{Data Analysis}

Data, were collected Problem-Solving Inventory, Metacognitive Awareness Inventory, Logical Reasoning Test Inventory, and Critical Thinking Inventory measurement tools to investigate the effect of problem-solving strategy instruction. Data was handled into the computer environment and analyzed using by IBM SPSS 21 (Statistical Package for Social Sciences) software. To compare pre and post-test scores of groups, independent sample t-test, to compare groups' scores before and after the instruction, dependent Sample t-test, to compare experimental groups' post scores of the tests correlations degree, Pearson correlation analysis was used. Paired sample t-test was also conducted for comparing experimental groups' factors scores of the Problem Solving Inventory before and after the instruction. 


\section{Results and Discussion}

Firstly, the Kolmogorov-Smirnov test was performed to decide if a sample comes from a population with a specific distribution. It was determined that the values obtained at the end of this test ( $p>.05)$ were normally distributed in the study universe and therefore it was decided to use parametric analysis methods for each test. To compare pre and post-test scores of groups, an independent sample t-test were used (Table 1).

Table 1. Independent Sample t-test Results of Group's Test Scores.

\begin{tabular}{|c|c|c|c|c|c|c|c|c|}
\hline & Test & Group & $\mathrm{N}$ & Mean & Standard Deviation & df & $\mathrm{t}$ & $p$ \\
\hline \multirow[t]{5}{*}{ Metacognitive Awareness Test } & Pre-test & Experimental & 30 & 1.02 & 15.03 & 58 & .77 & .443 \\
\hline & & Control & 30 & 1.00 & 5.66 & & & \\
\hline & Post-test & Experimental & 30 & 2.07 & 25.09 & 58 & 23.06 & $.00^{*}$ \\
\hline & & Control & 30 & 1.00 & 3.91 & & & \\
\hline & Test & Group & $\mathrm{N}$ & Mean & Standard Deviation & df & $\mathrm{t}$ & $\mathrm{p}$ \\
\hline \multirow[t]{5}{*}{ Critical Thinking Test } & Pre-test & Experimental & 30 & 2.18 & 20.34 & 58 & .89 & .37 \\
\hline & & Control & 30 & 2.13 & 20.44 & & & \\
\hline & Post-test & Experimental & 30 & 2.98 & 6.47 & 58 & 21.16 & $.00^{*}$ \\
\hline & & Control & 30 & 2.16 & 20.37 & & & \\
\hline & Test & Group & $\mathrm{N}$ & Mean & Standard Deviation & df & $\mathrm{t}$ & $p$ \\
\hline \multirow[t]{5}{*}{ Problem Solving Skills Test } & Pre-test & Experimental & 30 & 74.56 & 10.80 & 58 & .077 & .93 \\
\hline & & Control & 30 & 74.36 & 9.23 & & & \\
\hline & Post-test & Experimental & 30 & 1.06 & 7.67 & 58 & 16.76 & $.00^{*}$ \\
\hline & & Control & 30 & 72.93 & 7.95 & & & \\
\hline & Test & Group & $\mathrm{N}$ & Mean & Standard Deviation & $\mathrm{df}$ & $\mathrm{t}$ & $\mathrm{p}$ \\
\hline \multirow[t]{4}{*}{ Logical Reasoning Test } & Pre-test & Experimental & 30 & 3.66 & 1.15 & 58 & .11 & .91 \\
\hline & & Control & 30 & 3.63 & 1.12 & & & \\
\hline & Post-test & Experimental & 30 & 8.23 & 1.22 & 58 & 14.25 & $.00^{*}$ \\
\hline & & Control & 30 & 3.80 & 1.18 & & & \\
\hline
\end{tabular}

As shown in Table 1, there is no statistically significant difference in the independent sample t-test, which was used to determine the variance between the pre-test scores of the participants in the control and experimental groups for metacognitive awareness, critical thinking, problem solving and logical reasoning tests. Also, as observed in Table 1, there is a statistically significant difference in favor of the experimental group at the end of the independent sample t-test, which was applied for determining the variance between metacognitive awareness, critical thinking, problem solving and logical reasoning posttest scores of participants in the control and experimental groups. To compare groups' scores before and after the instruction, a dependent sample t-test was conducted (Table 2).

As shown in Table 2, there is no statistically significant difference at the end of the dependent sample t-test, which was used to determine the variance between the pre-test and post-test scores of the participants in the control groups for metacognitive awareness, critical thinking, problem-solving and logical reasoning tests. Also, as shown in Table 2, there is a statistically significant difference in favor of the post-test at the end of the dependent sample t-test, which was used for determining the difference between metacognitive awareness, critical thinking, problem-solving and logical reasoning tests. To compare experimental groups' post scores of the test correlations degree, Pearson correlation analysis was used (Table 3).

The experimental group's metacognitive awareness, critical thinking, problem-solving and logical reasoning post-test scores. A paired sample t-test was also conducted for comparing experimental groups' factors scores of the Problem Solving Inventory before and after the instruction (Table 4). 
Table 2. Dependent Sample t-Test Results of Group's Test Scores.

\begin{tabular}{|c|c|c|c|c|c|c|c|c|}
\hline \multirow{5}{*}{ Metacognitive Awareness Test } & Group & Test & $\mathrm{N}$ & Mean & Standard Deviation & $\mathrm{df}$ & $\mathrm{t}$ & $\mathrm{p}$ \\
\hline & Experimental & Pre-test & 30 & 1.02 & 15.03 & 29 & -19.31 & $.00 *$ \\
\hline & & Post-test & 30 & 2.07 & 25.09 & & & \\
\hline & Control & Pre-test & 30 & 1.00 & 5.66 & 29 & -.17 & .86 \\
\hline & & Post-test & 30 & 1.00 & 3.91 & & & \\
\hline \multirow{5}{*}{ Critical Thinking Test } & Group & Test & $\mathrm{N}$ & Mean & Standard Deviation & df & $\mathrm{t}$ & $\mathrm{p}$ \\
\hline & Experimental & Pre-test & 30 & 2.18 & 20.34 & 29 & -20.52 & $.00 *$ \\
\hline & & Post-test & 30 & 2.98 & 6.47 & & & \\
\hline & Control & Pre-test & 30 & 2.13 & 20.44 & 29 & -1.31 & .19 \\
\hline & & Post-test & 30 & 2.16 & 20.37 & & & \\
\hline \multirow{5}{*}{ Problem Solving Skills Test } & Group & Test & $\mathrm{N}$ & Mean & Standard Deviation & $\mathrm{df}$ & $\mathrm{t}$ & $\mathrm{p}$ \\
\hline & Experimental & Pre-test & 30 & 74.56 & 10.80 & 29 & -14.67 & $.00 *$ \\
\hline & & Post-test & 30 & 1.06 & 7.67 & & & \\
\hline & Control & Pre-test & 30 & 74.36 & 9.23 & 29 & 1.39 & .174 \\
\hline & & Post-test & 30 & 72.93 & 7.95 & & & \\
\hline \multirow{5}{*}{$\begin{array}{l}\text { Logical Reasoning } \\
\text { Test }\end{array}$} & Group & Test & $\mathrm{N}$ & Mean & Standard Deviation & $\mathrm{df}$ & $\mathrm{t}$ & $\mathrm{p}$ \\
\hline & Experimental & Pre-test & 30 & 3.66 & 1.15 & 29 & -16.66 & $.00 *$ \\
\hline & & Post-test & 30 & 8.23 & 1.22 & & & \\
\hline & Control & Pre-test & 30 & 3.63 & 1.12 & 29 & -1.22 & .23 \\
\hline & & Post-test & 30 & 3.80 & 1.18 & & & \\
\hline
\end{tabular}

Table 3. Pearson Correlation Analysis Results of Experimental Group's Post-Test Scores.

Tests' Scores

Metacognitive Awareness

Critical Thinking

Problem Solving Skills

Logical Reasoning
Metacognitive Awareness

Critical Thinking

1

$.83 * *$

1

$.76 * *$

1

$.88 * *$
$.76 * *$
1

Logical Reasoning

$.87 * *$

$84 * *$

$.79 * *$

1

Table 4. Paired Sample t-Test Results of Problem Solving Inventory' Sub-Factors.

\begin{tabular}{|c|c|c|c|c|c|c|c|}
\hline Group & Test & $\mathrm{N}$ & Mean & Standard Deviation & $\mathrm{df}$ & $\mathrm{t}$ & $p$ \\
\hline \multirow[t]{2}{*}{ Confident } & Pre-test & 30 & 22.60 & 7.98 & 29 & 10.26 & $.00 *$ \\
\hline & Post-test & 30 & 7.76 & 1.27 & & & \\
\hline \multirow[t]{2}{*}{ Thoughtful } & Pre-test & 30 & 12.06 & 3.50 & 29 & -23.28 & $.00 *$ \\
\hline & Post-test & 30 & 25.23 & 2.78 & & & \\
\hline \multirow[t]{2}{*}{ Avoidant } & Pre-test & 30 & 16.86 & 3.27 & 29 & 11.08 & $.00 *$ \\
\hline & Post-test & 30 & 7.33 & 3.25 & & & \\
\hline \multirow[t]{2}{*}{ Evaluating } & Pre-test & 30 & 5.96 & 1.44 & 29 & -28.01 & $.00 *$ \\
\hline & Post-test & 30 & 16.43 & 1.77 & & & \\
\hline \multirow[t]{2}{*}{ Self-confident } & Pre-test & 30 & 9.56 & 2.26 & 29 & -30.50 & $.00 *$ \\
\hline & Post-test & 30 & 28.33 & 2.65 & & & \\
\hline \multirow[t]{2}{*}{ Planned } & Pre-test & 30 & 7.50 & 1.61 & 29 & -36.34 & $.00 *$ \\
\hline & Post-test & 30 & 21.66 & 1.68 & & & \\
\hline
\end{tabular}

Paired sample t-test results indicate that there were significant differences between pre and post scores of factor scores named as; confident, thoughtful, avoidant, evaluating, self-confident, planned.

Problem-solving skills are listed among the 21st Century skills, are associated with high-level learning skills such as metacognitive awareness, critical thinking, and logical thinking skill as mentioned above. It is considered that the development of each skill also creates a developing effect on each other. In this context, present research examines the effects of the Extended Problem-Solving Strategy, which was implemented during the physics lessons on the pre-service science teacher's problem-solving skills, critical thinking, metacognitive awareness skills, and logical reasoning skills, in comparison with traditional physics 
lessons. The model of the research consists of an experimental design with pre-test and post-test control groups.

The results of the research indicate that the post scores of the experimental group students increased significantly compared to the pre scores while there is no difference between the pre and posttest scores of the control group students after the implementations. This result shows that the students of the selected control and experiment groups did not stay at the same level in terms of metacognitive awareness, critical thinking, problem-solving and logical thinking skills. It is also stated that there is a significant positive correlation between metacognitive awareness, critical thinking, problem-solving and logical thinking skill post-test scores of the experimental group students. Another important finding of this study is to show that there is a significant relationship between experimental group students' sub-factor score changes after the implementation.

The positive effects of Extended Problem-Solving Strategy implementation can be supported by relevant studies in the literature, which revealed the positive effects of the use of any problem-solving strategy in physics and science education at different levels about (Bolton \& Ross, 1997; Çalışkan et al., 2007; Dhillon, 1998; Dufresne, Gerace, Hardiman, \& Touger, 1993; Dufrense et al., 1997; Docktor et al., 2015; Gök, 2014, Heller \& Reif, 1984; Hollingworth \& McLoughlin, 2001; Lawson, 1978; Larkin \& Reif, 1979; Lucangeli, Galderisi, \& Cornoldi, 1995; Olaniyan, \& Govender, 2018; Selçuk et al., 2008; Wright \& Williams, 1986).

The results of this research have been presented for the first time in this research in the physics area had been encountered. This research shows the positive effects of the "Extended Problem-Solving Strategy" implementation in the physics course at the university level on the metacognitive awareness, critical thinking, problem solving and logical thinking skills and each of these skills affects the other skills positively (Halpern, 2010; Hollingworth \& McLoughlin, 2001; Lawson, 1978, 2004; Leniz \& Guisasola, 2017; Mendez, Sanchez, \& Mendez, 2017; Lucangeli, Galderisi, \& Cornoldi, 1995; Tiruneh, Verburgh, \& Elen, 2017; Leniz, Zuza, \& Guisasola, 2017; Trisnowati \& Sumardi, 2019).

\section{Conclusion}

Based on the result and discussion can be concluded that high order thinking skills of students can be developed or improved by "Extended Problem-Solving Strategy" implementation. The results of this implementation have been presented for the first time in this research in the physics area had been encountered. The following studies of Extended Problem-Solving Strategy can be performed in the other topics of physics such as; electromagnetism, thermodynamics, optic, etc. at physics courses. Also, problemsolving performance evaluations, creative thinking skills, conceptual understanding, achievement, selfefficacy, self-regulation studies can be performed.

\section{References}

Akın, A., Abacı, R., \& Çetin, B. (2007). Bilişötesi farkındalık envanteri'nin türkçe formunun geçerlik ve güvenirlik çalışması. Kuram ve Uygulamada Eğitim Bilimleri, 7(2), 655-680.

Bissell, A.N. \& Lemons, P.P. (2006). A new method for assessing critical thinking in the classroom. BioScience, 56(1), 66-72.

Bolton, J., \& Ross, S. (1997). Developing students' physics problem-solving skill. Physics Education, 32, 17685.

Çalışkan, S. (2007). Problem çözme stratejileri öğretiminin fizik başarısı, tutumu, özyeterliği üzerindeki etkileri ve strateji kullanımı. (Unpublished Doctoral Dissertation). Dokuz Eylul University, Institute of Educational Science. 
Dhillon, A.S. (1998). Individual differences within problem-solving strategies used in physics. Science Education, 82(3); 279-405.

Docktor, J. L., Strand, N. L., Mestre, J.P., \& Ross, B.H. (2015). Conceptual problem solving in high school physics. Physical Review Special Topics- Physics Education Research, 11, 1- 13.

Dufrense, R., Gerace, W., \& Leonard, J. (1997). Solving physics problems with multiple representations. Physics Teacher, 35, 270-275.

Ertmer, P.A. \& Newby, T.J. (1996). The expert learner: Strategic, self-regulated, and reflective. Instructional Science, 24(1), 1-24.

Facione, P. A. \& Facione, N. C. (1992). The california critical thinking dispositions inventory. Millbrae, CA: California Academic Press.

Geban, Ö., Aşkar, P. \& Özkan, İ. (1992). Effects of computer simulations and problem solving approaches on high school students. Journal of Educational Research, 86, 5- 10.

Gök, T. (2014). Peer instruction in the physics class room: effects on gender difference performance, conceptual learning, and problem solving. Journal of Baltic Science Education, 13(6), 776-788.

Gök, T. (2015). An investigation of students' performance after peer instruction with stepwise problemsolving strategies. International Journal of Science and Mathematics Education, 13(3), 562-582.

Häkkinen, P., Järvelä, S., Mäkitalo-Siegl, K., Ahonen,A., Näykki, P. \& Valtonen, T. (2017). Preparing teacherstudents for twenty-first-century learning practices (PREP 21): a framework for enhancing collaborative problem-solving and strategic learning skills. Teachers and Teaching, 23(1), 25-41.

Halim, A., Yusrizal, Y., Susanna, \& S., Tarmizi, T. (2016). An analysis of students' skill in applying the problem solving strategy to the physics problem settlement in facing AEC as global competition. Jurnal Pendidikan IPA Indonesia, 5(1), 1-5.

Halpern, D. F. (2010). The halpern critical thinking assessment: Manual. Modling, Austria: Schuhfried GmbH.

Heller, J. I., \& Reif, F., (1984). Prescribing effective human problem-solving processes: problem description in physics. Cognition and Instruction, 1, 177-216.

Heppner, P. P., \& Petersen, C. H. (1982). The development and implications of a personal problem solving inventory. Journal of Counseling Psychology, 29(1), 66-75.

Hollingworth, R.W., \& McLoughlin, C. (2001). Developing science students' metacognitive problem solving skills online. The Australasian Journal of Educational Technology, 17(1), 50-63.

Ince, E. (2017). Fizik Öğretiminde Problem Çözme. Cezve Kitabevi, İstanbul.

Kökdemir, D. (2003). Belirsizlik durumlarında karar verme ve problem çözme. (Unpublished Doctoral Dissertation). Ankara University, Institute of Social Science.

Larkin, J. H. \& Reif, F. (1979). Understanding and teaching problem-solving in physics. European Journal of Science Education, 1, 191-203.

Lawson, A. (1978). The development and validation of a classroom test of formal reasoning. Journal of Research in Science Teaching, 15(1), 11-24.

Lawson, A. (2004). The nature and development of scientific reasoning: a synthetic view. International Journal of Science and Mathematics Education, 2(3), 307-338.

Lawson, A.E. (1982). The reality of general cognitive operations. Science Education, 66(2), 229-241.

Leniz, A., Zuza, K. \& Guisasola, J. (2017). Students' reasoning when tackling electric field and potential in explanation of dc resistive circuits. Physical Review Physics Education Research, 13, 010128.

Lucangeli, D., Galderisi, D., Cornoldi, C. (1995). Specific and general transfer effects of meta-memory training. Learning Disabilities Research and Practice, 10, 11-21.

Marlina, A., Nor Hasniza, I., Abdul Halim, A., Johari, S., \& Nurshamela, S. (2014). Physics problem solving: selecting more successful and less successful problem solvers. International Conference of Teaching Assessment and Learning, 186-191.

Mendez, D., Sanchez, J.H. \& Mendez, M. (2017). The effect in the action of the professor and the problems in the development of abstract reasoning in future teacher. American Journal of Educational Research, 5(3), 267-272. 
Moser, C. A., \& Kalton, G. (1971). Survey methods in social investigation, London, Heinemann.

Olaniyan, A.O. \& Govender, N. (2018). Effectiveness of Polya problem-solving and target-task collaborative learning approaches in electricity amongst high school physics students. Journal of Baltic Science Education, 17(5), 765-777.

Patenting Turkey. (2018, January 20). http://www.patentleturkiye.gov.tr/patentleturkiye/

Sahin, N., Sahin, H. H., \& Heppner, P. P. (1993). Psychometric properties of the problem solving inventory in a group of Turkish university studies. Cognitive Therapy Research, 17, 379-396.

Schraw, G., \& Dennison S. R. (1994). Assessing metacognitive awareness. Contemporary Educational Psychology, 19, 460-470.

Selçuk, G.S., Çalışkan, S., \& Erol, M. (2008). The effects of problem solving instruction on physics achievement, problem solving performance and strategy use. Latin American Journal of Physics Education, 2(3), 151-166.

Serway, R.A. \& Beichner, R.J. (2007). Fen ve Mühendislik için Fizik-1 (Beşinci Baskıdan Çeviri). Ankara: Palme Yayıncilık.

Tezbaşaran A. A. (2011). Öğretim programlarındaki kazanımlarla geliştirilmesi beklenen düşünme becerileri üzerine. Cito Eğitim: Kuram ve Uygulama, 13, 13 - 22.

Tiruneh, D. T., Verburgh, A. \& Elen, J. (2014). Effectiveness of critical thinking instruction in higher education: a systematic review of intervention studies. Higher Education Studies, 4(1), 1-17.

Tobin, K. G. \& Capie, W. (1981). Development and validation of a group test of logical thinking. Educational and Psychological Measurement, 41, 413-424.

Trisnowati. E., \& Sumardi, Y. (2019). Developing the student worksheet with problem-solving approach to improve critical thinking skills and the concept understanding of physics. Momentum: Physics Education Journal, 3(1), 2019, 32-41.

Wright, D. S. \& Williams, C. D. (1986). A wise strategy for introductory physics. The Physics Teacher, 211216.

Zou, X. (2001). The role of work-energy bar charts as a physical representation in problem solving. Physics Education Research Conference, July 25-26, Rochester, New York. 